\title{
Amelioration of Cisplatin-Induced Kidney Injury by Pometia pinnata
}

\author{
Adrian ${ }^{1}$, RA Syahputra ${ }^{2, *}$, Sukirman Lie ${ }^{3}$, SE Nugraha ${ }^{4}$, PC Situmorang ${ }^{5}$
}

Adrian', RA Syahputra',*, Sukirman Lie $^{3}$, SE Nugraha ${ }^{4}$, PC Situmorang ${ }^{5}$

'Faculty of Medicine, Universitas Prima Indonesia, Sumatera Utara, Medan, INDONESIA. ${ }^{2}$ Department of Pharmacology, Faculty of Pharmacy, Universitas Sumatera Utara, Sumatera Utara, Medan, INDONESIA.

${ }^{3}$ Akademi Keperawatan Colombia Asia, Sumatera Utara, Medan, INDONESIA.

${ }^{4}$ Department of Pharmaceutical Biology, Faculty of Pharmacy, Universitas Sumatera Utara, Sumatera Utara, Medan, INDONESIA.

Utara, Medan, INDONESIA.
${ }^{5}$ Department of Biology, Faculty of Mathematics and Natural Sciences, Universitas Sumatera Utara Medan, INDONESIA.

\section{Correspondence}

\section{R.A Syahputra}

Department of Pharmacology, Faculty of Pharmacy, Universitas Sumatera Utara,

Sumatera Utara, Medan, INDONESIA.

Phone no: +6282274736966

E-mail: rony@usu.ac.id

History

- Submission Date: 04-07-2021;

- Review completed: 04-07-2021;

- Accepted Date: 26-07-2021.

DOI : 10.5530/pj.2021.13.159

Article Available online

http://www.phcogj.com/v13/i5

Copyright

(C) 2021 Phcogj.Com. This is an openaccess article distributed under the terms of the Creative Commons Attribution 4.0 International license.

\begin{abstract}
Introduction: Cisplatin is one of the most effective anticancer drugs. But using cisplatin can cause very serious nephrotoxicity and acute kidney injury (AKI). Pometia pinnata (PE) or commonly referred to as matoa is a typical plant, especially Papua, Indonesia. Pometia pinnata belongs to the Sapindaceae family This study aimed to determined the nephroprotective activity of the extract ethanol pometia pinnata on rats induced cisplatin. Methods: 30 rats are divided into six groups, each group were contained 5 rats. Group I was a normal group which rats only given CMC (carboxy methyl celluloce). Group II was a negative group which rats injected $7 \mathrm{mg} / \mathrm{kgbw}$ of Cisplatin in day 3 . Group III was a positive group which rats given vitamin C $1 \%$ from day 1 to 7 and in day 3 rats were injected cisplatin. Group IV-VI were extract groups (100 mg / kgbb, $200 \mathrm{mg} / \mathrm{kgb}, 400 \mathrm{mg} / \mathrm{kgbb}$ ) which rats orally given extract from day 1 to 7 and in day 3 rats were injected cisplatin. On day 8 rats were injected ketamine $1 \%$ which directly took the blood from the heart. Results: The result shows that EEPE on rats biochemical parameters including urea, creatinine, uric acid. Group II showed that there was a significant increase $(p<0.05)$ compared to the normal group that was not given cisplatin and extracts. Whereas in the group given the extract in groups IV, $\mathrm{V}$, and $\mathrm{VI}$ there was a reduction in biochemical parameters because the Pometia leaf extract had high antioxidant activity so that it had nephroprotective activity. extract ethanol pometia pinnata can reduced the level of sodium, potassium and chloride of each group after receiving cisplatin. Statistically group II that only given cisplatin has significantly different with group I $(p<0,05)$ and also statically different with group VI $(p<0,05)$. Key words: Cisplatin, Pometia pinnata, Kidney injury.
\end{abstract}

\section{INTRODUCTION}

Cisplatin (cis-diamminedichloroplatinum II, CDDP) is one of the most effective anticancer drugs. But using cisplatin can cause very serious nephrotoxicity and acute kidney injury (AKI). Nearly $30-40 \%$ of cisplatin use in patients causes neprotoxicity as a result of CDDP accumulation and kidney biotransformation. Until now, only amifostine is widely used as a nephroprotective agent during cisplatin treatment but has side effects such as hypocalemia, hypotension, and vertigo. Cisplatin can increase biomarkers of kidney damage such as KIM-1 (Kidney injury molecule-1), cystatin C and NGAL (Neutrophil gelatinase) ${ }^{1-4}$.

Two of the largest clinical manifestations of nephrotoxicity due to the use of cisplatin is acute renal failure (20-30\%) and hypomagnesemia (40$100 \%)$. Acute renal failure can be detected by an increase in Blood Urea Nitrogen (BUN) and serum creatinine. Dialysis costs are expensive and weaknesses of cisplatin chemotherapy supportive therapy that has been provided at this time to encourage research on other materials that can be used as chemoprotective agents to prevent and reduce the use of cisplatin nephrotoxicity ${ }^{5,6}$.

The main mechanism of cisplatin is an agent becomes activated intracellularly by akuasi one of two groups chloride groups and then covalently binds to DNA, forming a DNA adduct. This process activates various signal transduction pathways, for example, in DNA-damage recognition and repair, cell cycle arrest, and programmed cell death / apoptosis. ${ }^{7}$ However, the clinical success of cisplatin is limited because of severe side effects and intrinsic or acquired resistance during treatment. Unfortunately, resistance has limited the effectiveness of these agents in most diseases. Resistance to platinum-based chemotherapy can be intrinsic or acquired and may be mediated by factors outside or inside cancer cells or on the cell membrane. ${ }^{8,9}$ The toxicity due to the use of cisplatin is very dangerous, so that in its use, additional therapy is needed, both traditional and modern. Traditional therapy is often used by people, especially in Indonesia, one of which is the use of herbs.

Pometia pinnata (PE) or commonly referred to as matoa is a typical plant, especially Papua, Indonesia. Pometia pinnata belongs to the Sapindaceae family. Matoa fruit has a characteristic and combined taste of rambutan, longan and a little durian taste. PE is cultivated by local people because it has economic value. There is very little research on pometia pinnata, such as the study conducted by Ni wayan, which revealed that the ethanol extract of matoa leaves has strong antioxidant activity, qualitative phytochemical screening shows that the ethanol extract of matoa leaves contains flavonoids and tannins. ${ }^{10,11}$ Another study reported that the ethanol extract of the matoa fruit peel contains strong antioxidant activity and has antibacterial activity by inhibiting the bacteria Escherichia coli, Bacillus cereus and Staphylococcus aureus. Another study also revealed that the ethanol extract of the matoa fruit peel contains high levels of phenols and flavonoids compared to gallic acid and quercetin. ${ }^{12,13}$ This study aim to determine the nephroprotective activity of Pometia pinnata ethanol extract.

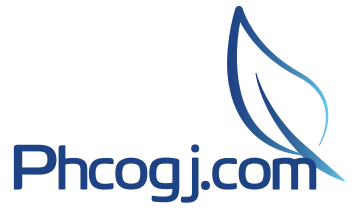

Cite this article: Adrian, Syahputra RA, Lie S, Nugraha SE, Situmorang PC. Amelioration of Cisplatin-Induced Kidney Injury by Pometia pinnata. Pharmacogn J. 2021;13(5): 1257-1268. 


\section{MATERIALS AND METHODS}

\section{Extract Ethanol Pometia Pinnata Preparation}

$700 \mathrm{~g}$ poweder dry fruit of Pometia pinnata dissolved using $96 \%$ ethanol then steer occasionally, then the solution is macerated for 7 days and steer occasionally every day, then the solution is filtered with whattman paper no 1 , the filter results are then forgotten using a rotary evaporator under reduced pressure and the solvent is evaporated until crude extract / extract ethanol of PE (EEPE) is obtained. Then performed phytochemical screening (alkaloids, flavonoids, tannins, saponins, glycosides, steroids / triterpenoids).

\section{Animal Handling}

30 normal health and wight between 150 - $200 \mathrm{~g}$ of rats were used in the experimental study. Rats are placed in plastic cages that are adjusted to a humidity of $40-60 \%$ and under dark / light cycle 12 hours. and also rats were given a pellet food from cratachem manufacturing and drink ad libitum.

\section{Research design}

30 rats are divided into six groups, each group were contained 5 rats. Group I was a normal group which rats only given CMC (carboxy methyl celluloce). Group II was a negative group which rats injected 7 $\mathrm{mg} / \mathrm{kgbw}$ of Cisplatin in day 3. Group III was a positive group which rats given vitamin $\mathrm{C} 1 \%$ from day 1 to 7 and in day 3 rats were injected cisplatin. Group IV-VI were extract groups (100 mg / kgbb, $200 \mathrm{mg}$ / kgb, $400 \mathrm{mg} / \mathrm{kgbb}$ ) which rats orally given extract from day 1 to 7 and in day 3 rats were injected cisplatin. On day 8 rats were injected ketamine $1 \%$ which directly took the blood from the heart

\section{Biochemical parameters analysis}

$3 \mathrm{ml}$ of blood from each rat were centrifugated $4000 \mathrm{RPM}\left(5^{\circ} \mathrm{C}\right)$ for 10 menit after that $0.5 \mathrm{ml}$ of supernatant was taken and directly put into cobas 6000 for examining the levels of Urea, Creatinine, Uric Acid. 0.5 $\mathrm{ml}$ of supernatant also put into cobas b 221 for exmining the levels of Sodium, Potassium, and Chloride. (Roche Diagnostic, Swiss).

\section{NGAL, SOD, and MDA analysis}

1 gram of kidney tissue are taken and homogenized in homogenator tissue with $10 \mathrm{ml}$ of $\mathrm{PBS} \mathrm{pH} \mathrm{7,4}$ during 5 minutes, supernatant are taken and continue to analysis the level of NGAL, SOD, and MDA by using ELISA reader at $450 \mathrm{~nm}$ (Abclonal, China).

\section{Data analysis}

Data analysis in this study used SPSS (statistical program for social sciences) version 21 using the one-way ANOVA (Analysis of Variance) test. $\mathrm{p}<0.05$ if there is a significant difference between groups, $\mathrm{p}>0.05$ if there is no difference between groups.

\section{RESULTS}

\section{Biochemical Parameters Analysis of Urea, Creatinine, and Uric Acid}

Measurement of serum biochemical parameters is required to analyze renal damage resulting from exposure to cisplatin. In this study, the measurement of levels of urea, creatinine, uric acid, Data can be seen in table 1. Below:

Table 1 shows the effect of EEPE on rats biochemical parameters including urea, creatinine, uric acid. Group II showed that there was a significant increase $(\mathrm{p}<0.05)$ compared to the normal group that was not given cisplatin and extracts. Whereas in the group given the extract in groups IV, V, and VI there was a reduction in biochemical parameters because the matoa leaf extract had high antioxidant activity so that it had nephroprotective activity.

\section{Biochemical Parameters Analysis of Sodium, Potassium, and Chloride}

Measurement of serum biochemical parameters is required to analyze renal damage resulting from exposure to cisplatin. In this study, the measurement of levels of sodium, potassium and chloride, Data can be seen in table 2.

Table 2 show that extract ethanol pometia pinnata can reduced the level of sodium, potassium and chloride of each group after receiving cisplatin. Statistically group II that only given cisplatin has significantly different with group I $(\mathrm{p}<0,05)$ and also statically different with group $\mathrm{VI}(\mathrm{p}<0,05)$.

\section{NGAL, SOD, and MDA Analysis}

Neutrophil Gelatinase (NGAL) is one of the specific parameters of kidney damage. If there is an increase in NGAL levels in serum and urine then it is an indication of damage to the kidneys. Sodium dismutase (SOD) is an endogenous antioxidant parameter used to analyze whether there is a decrease when cisplatin is given to rats. Meanwhile, Malondialdehyde (MDA) was used to analyze the occurrence of lipid peroxidation, especially in the kidneys due to exposure to cisplatin. The data can be seen in table 3 .

In the group that was only given cisplatin, group II showed an increase in neutrophil gelatinase (NGAL) levels, while in the group give $n$ extracts, namely groups IV, V, and VI, there was a decrease in NGAL levels. Sodium superoxide levels in group II who were given cisplatin occur a significant loss compared with the group given the ethanol extract of the leaves matoa which causes an increase in SOD. While MDA levels increased in the group given cisplatin, while in the group given the ethanol extract of the leaves matoa decreased levels of MDA.

\section{DISCUSSION}

The parameters of kidney damage that are most often used are urea and creatinine, if there is an increase in these levels, it is feared that there will be structural and functional disorders of the kidneys. Creatinine is the end product of muscle creatine phosphate, and usually produced with a constant level (depending on muscle mass). Most of creatinine excreted from the blood via the kidneys, primarily through glomerular filtration also through the proximal tubule secretion. If the filtration in the kidneys decreases, the creatinine level in the blood will increase. Every day, $12 \%$ of creatine is converted to creatinine. Serum creatinine is an important indicator of renal physiology since creatinine is a product of muscle metabolism that is excreted in unchanged form via the kidneys ${ }^{14}$. Urea or urea is a protein catabolic waste substance that is formed in the liver and is filtered and reabsorbed in the kidneys. If kidney function is impaired, urea will accumulate in the blood, a condition called uremia. This situation can be fatal. To overcome this, the cause of kidney failure must be addressed or the patient must undergo dialysis to remove urea and other waste products ${ }^{15}$. In this study, it was found that there was an increase in urea and creatinine in cisplatin-induced rats in group II (Tables 1 and 2). There are so many studies that prove that cisplatin causes kidney damage. The mechanisms that contribute to renal dysfunction were exposed to cisplatin is in the form of direct tubular toxicity in the form of apoptosis and necrosis mediated through inflammation, ROS, calcium overload, activation of phospholipase, decreased levels of glutathione, and inhibition of mitochondrial respiratory chain function. It has been reported that administration of $5 \mathrm{ml} / \mathrm{kg}$ bw cisplatin ( $0.1 \%$ in saline) by ip acute renal failure in mice within 72 hours after administration, while it has also been reported the occurrence of kidney failure with the same doses 
Table 1: Biochemical parameters (Urea, Creatinine, Uric Acid) Levels of each Groups.

\begin{tabular}{lccccccc}
\hline \multirow{2}{*}{ Parameters } & \multirow{2}{*}{ Unit } & \multicolumn{5}{c}{ Groups (Mean \pm SD) } \\
\cline { 3 - 7 } & & Group I & Group II & Group III & Group IV & Group V & Group VI \\
\hline Urea & $\mathrm{mg} / \mathrm{dL}$ & $30,41 \pm 2.54^{*}$ & $98,45 \pm 5.76^{*}$ & $29,15 \pm 2.44^{*}$ & $54,58 \pm 3.81$ & $48,42 \pm 3.16$ & $32,41 \pm 2.62^{*}$ \\
Creatinine & $\mathrm{mg} / \mathrm{dL}$ & $0,97 \pm 0.01^{*}$ & $3,36 \pm 0.53^{*}$ & $0,86 \pm 0.08^{*}$ & $1,47 \pm 0.29$ & $0,91 \pm 0.073$ & $0,78 \pm 0.062^{*}$ \\
Uric Acid & $\mathrm{mg} / \mathrm{dL}$ & $0,61 \pm 0.04^{*}$ & $2,45 \pm 0.21^{*}$ & $0,58 \pm 0.023^{*}$ & $1,58 \pm 0.18$ & $1,02 \pm 0.098$ & $0,65 \pm 0.044^{*}$
\end{tabular}

* $(p<0,05)$ significant different from normal group (Group I)

$\#(p<0,05)$ significant different from control (-) group (Group II)

Table 2: Biochemical parameters (sodium, potassium, chloride) Levels of each Groups.

\begin{tabular}{lccccccc}
\hline \multirow{2}{*}{ Parameters } & \multirow{2}{*}{ Unit } & \multicolumn{5}{c}{ Groups (Mean \pm SD) } \\
\cline { 3 - 8 } & & Group I & Group II & Group III & Group IV & Group V & Group VI \\
\hline Sodium & $\mathrm{mmol}$ & $140,56 \pm 10.22^{\#}$ & $234,67 \pm 20.48^{*}$ & $135,23 \pm 9.84^{*}$ & $205,66 \pm 19.86$ & $152,88 \pm 12.41$ & $140,4 \pm 10.51^{*}$ \\
Potassium & $\mathrm{mmol}$ & $5,42 \pm 0.48^{\#}$ & $23,60 \pm 2.36^{*}$ & $4,88 \pm 0.38^{\#}$ & $18,48 \pm 1.86$ & $10,42 \pm 0.84$ & $5,28 \pm 0.46^{\#}$ \\
Chloride & $\mathrm{mmol}$ & $98,67 \pm 7.46^{\#}$ & $320,67 \pm 18.72^{*}$ & $85,21 \pm 6.54^{*}$ & $250,56 \pm 12.65$ & $185,18 \pm 10.44$ & $95,86 \pm 8.03^{\#}$
\end{tabular}

$*(p<0,05)$ significant different from normal group (Group I)

$\#(p<0,05)$ significant different from control (-) group (Group II)

Table 3: NGAL, SOD, and MDA Levels of each Groups.

\begin{tabular}{lccccccc}
\hline & \multirow{2}{*}{ Parameters } & Unit & \multicolumn{5}{c}{ Groups (Mean \pm SD) } \\
\cline { 3 - 7 } & & Group I & Group II & Group III & Group IV & Group V & Group VI \\
\hline Serum NGAL & $\mathrm{ng} / \mathrm{mL}$ & $0,1304 \pm 0,047^{*}$ & $0,5839 \pm 0,342^{*}$ & $0,1634 \pm 0,036^{\#}$ & $0,4237 \pm 0,151$ & $0,347 \pm 0,019$ & $0,1217 \pm 0,021^{\#}$ \\
SOD & $\mathrm{pg} / \mathrm{mL}$ & $22.76 \pm 1.05^{*}$ & $10.45 \pm 0.58^{*}$ & $24.48 \pm 1.08^{*}$ & $15.67 \pm 0.86$ & $16.58 \pm 0.93$ & $24.62 \pm 1.05^{*}$ \\
MDA & $\mu \mathrm{M} / \mathrm{L}$ & $5.62 \pm 0.06^{*}$ & $12.87 \pm 0.69^{*}$ & $5.41 \pm 0.053^{*}$ & $10.44 \pm 0.23$ & $6.45 \pm 0.081$ & $5.47 \pm 0.058^{*}$
\end{tabular}

${ }^{*}(p<0,05)$ significant different from normal group (Group I)

$\#(p<0,05)$ significant different from control (-) group (Group II)

of cisplatin after five days injected. Model of cisplatin-induced renal failure in mice occurred at doses of $12 \mathrm{mg} / \mathrm{kg}$ bw, i.p; $18 \mathrm{mg} / \mathrm{kg} \mathrm{bb}$, i.p; $40 \mathrm{mg} / \mathrm{kg}$ bw, i.p ${ }^{16}$.

Cisplatin-induced nephrotoxicity is mediated by intracellular signaling pathways mitogen- activated protein kinase (MAPK). MAPK pathway is a series of stages of serine / threonine kinases that are activated by the presence of extracellular stress physical and chemical. These pathways regulate proliferation, differentiation, and cell defense. Three main lines of MAPK leads to extracellular regulated kinase (ERK), p38, and enzymes June N-terminal kinase / stress-activatedprotein kinase (JNK / SAPK). The mechanism of in vivo cisplatin nephrotoxicity occurs in a complex manner and including oxidative stress, apoptosis, inflammation, and fibrogenesis. High cisplatin concentrations can induce apoptosis via the caspase 9 dependent pathway. Hypoxia and mitochondrial damage also includes the effect of cisplatin-induced nephrotoxicity. Pathological changes induced nephrotoxicity of cisplatin mainly occurs in the proximal tubule S3 segment, perimeter cord. In this zone the kidneys more vulnerable to ischemia and damage. Hypoxic tubules were identified by staining pimonidazol on cisplatininduced nephrotoxicity. From analaisis result, the portion of cells that significantly indicates hypoxia renal proximal tubular cells ${ }^{17-20}$.

Damage mechanisms of acute renal failure caused by cisplatin is the inhibition of protein synthesis, DNA damage, mitochondrial injury and apoptosis in renal tubules. Cisplatin reduces the activity of nitric oxide, monocyte chemoattractant protein-1 and growth factors as well as improving tumor necrosis tissue factora, free radicals (ROS), causing kidney injury and inflammation. Cisplatin in a cell will interact with proteins and cellular components of microfilaments, cytoskeleton, peptides, RNA, and Glutathione (GSH). The conjugation of cisplatin with glutathione (GSH) produces reactive thiols which are free radicals. Thiol reactive causes decreased production of vascular endothelial growth factor (VEGF) that penestrasi impaired glomerular endothelial cells. Thiol reactive also trigger proximal tubular cell death due to oxidative stress so that the necessary antioxidants to cope ${ }^{21}$.
The initial process of biosynthesis of creatine takes place in the kidneys involving amino acids arginine and glycine. Creatine is converted to creatinine in an amount of $1.1 \%$ per day. On the formation of creatinine no reuptake mechanism by the body, so most of creatinine excreted through the kidneys. If renal dysfunction occurs, the creatinine filtration ability will decrease and the serum creatinine will increase. Increased levels of serum creatinine doubling indicates a decrease in kidney function by $50 \%$, as well as an increase in serum creatinine levels tripled reflecting a decline in kidney function by $75 \%{ }^{22}$. Kidney disease or blockage of urine flow from the kidney causes increased levels of urea and creatinine. Higher mean serum creatinine levels kidneys do not work properly. Creatinine levels may rise temporarily if dehydrated, have low blood volume, eat a lot of meat or drinking certain drugs. Creatinine dietary supplements may have the same effect ${ }^{23}$.

pometia pinnata is known to have high antioxidant activity and contains many secondary metabolites including flavonoids. The flavonoids found in Poemtia pinnata have an important role in reducing the radicalization process caused by cisplatin. The term flavonoids refers to the thousands of plant compounds with the same basic structure, phenylchromane, which allow the formation of several subclasses of flavonoids including flavonols, flavones, catechins, anthocyanidins, isoflavones, dihydroflavonols, and chalcones ${ }^{24}$. Variable amounts of these compounds are found in vegetables, fruits, nuts, spices, herbs, red wine and tea, among others. Flavonoids are one of the main classes of polyphenols, which have many pharmacological activities, exert antioxidant effect and are known to improve cardiovascular health, but little is known about their role in kidney function and disease ${ }^{25}$.

\section{CONCLUSION}

Ethanol extract of Pometia pinnata has nephroprotective effect on rats induced cisplatin by reducing the biochemical parameters such as urea, creatinine, uric acid, sodium, potassium, chloride, NGAL, and MDA while increase the SOD level. 


\section{REFERENCES}

1. Oh, S.M., Park, G., Lee, S.H., Seo, C.S., Shin, H.K. and Oh, D.S. Assessing the recovery from prerenal and renal acute kidney injury after treatment with single herbal medicine via activity of the biomarkers HMGB1, NGAL and KIM-1 in kidney proximal tubular cells treated by cisplatin with different doses and exposure times. BMC complementary and alternative medicine. 2017; 1(17): 1-9. https:// doi.org/10.1186/s12906-017-2055-y

2. Landau, S.I., Guo, X., Velazquez, H., Torres, R., Olson, E., GarciaMilian, R., Moeckel, G.W., Desir, G.V. and Safirstein, R. Regulated necrosis and failed repair in cisplatin-induced chronic kidney disease. Kidney international. 2019; 4(95): 797-814. DOI: 10.1016/j. kint.2018.11.042

3. Monisha, J., Roy, N.K., Padmavathi, G., Banik, K., Bordoloi, D., Khwairakpam, A.D., Arfuso, F., Chinnathambi, A., Alahmadi, T.A., Alharbi, S.A. and Sethi, G. NGAL is downregulated in oral squamous cell carcinoma and leads to increased survival, proliferation, migration and chemoresistance. Cancers. 2018; 10(7): 228. DOI: 10.3390/ cancers 10070228

4. Wang, W., Li, Z., Chen, Y., Wu, H., Zhang, S. and Chen, X. Prediction value of serum NGAL in the diagnosis and prognosis of experimental acute and chronic kidney injuries. Biomolecules. 2020; 10(7): 981. doi: 10.3390/biom10070981

5. Meza-Morales, W., Estévez-Carmona, M.M., Alvarez-Ricardo, Y., Obregón-Mendoza, M.A., Cassani, J., Ramírez-Apan, M.T., EscobedoMartínez, C., Soriano-García, M., Reynolds, W.F. and Enríquez, R.G. Full structural characterization of homoleptic complexes of Diacetylcurcumin with Mg, Zn, Cu, and Mn: cisplatin-level cytotoxicity in vitro with minimal acute toxicity in vivo. Molecules. 2019; 24(8): 1598. DOI: 10.3390/molecules 24081598

6. Tao, C.J., Lin, L., Zhou, G.Q., Tang, L.L., Chen, L., Mao, Y.P., Zeng, M.S., Kang, T.B., Jia, W.H., Shao, J.Y. and Mai, H.Q. Comparison of long-term survival and toxicity of cisplatin delivered weekly versus every three weeks concurrently with intensity-modulated radiotherapy in nasopharyngeal carcinoma. PloS one. 2014; 9(10): 110765. doi: 10.1371/journal.pone.0110765

7. Sadhukhan, P., Saha, S., Dutta, S. and Sil, P.C. Mangiferin ameliorates cisplatin induced acute kidney injury by upregulating Nrf-2 via the activation of PI3K and exhibits synergistic anticancer activity with cisplatin. Frontiers in pharmacology. 2018; 9(1): 638. DOI: 10.3389/ fphar.2018.00638

8. Sharma, S., Joshi, A. and Hemalatha, S. Protective effect of Withania coagulans fruit extract on cisplatin-induced nephrotoxicity in rats. Pharmacognosy research. 2017; 9(4): 354. DOI: 10.4103/ pr.pr_1_17

9. Neag, M.A., Mitre, C.I., Mitre, A.O., Morhan, V., Catinean, A., Botan, E.C., Melincovici, C.S., Muntean, D.M. and Buzoianu, A.D. Paradoxical effect of grape pomace extract on cisplatin-induced acute kidney injury in rats. Pharmaceutics. 2019; 11(12): 656. DOI: 10.3390/ pharmaceutics11120656

10. Irawan, C., Sulistiawaty, L., Rochaeni, H. and Lestari, P.S. Evaluation of DPPH free radical scavenging activity of Pometia pinnata from Indonesia. The Pharma Innovation. 2017; 6(8): 403.

11. Naidi, S.N., Khan, F., Tan, A.L., Harunsani, M.H., Kim, Y.M. and Khan, M.M. Photoantioxidant and antibiofilm studies of green synthesized Sn-doped CeO 2 nanoparticles using aqueous leaf extracts of Pometia pinnata. New Journal of Chemistry, 2021; 45(17): 7816-7829. https:// doi.org/10.1039/D1NJ00416F
12. Utari, F., Itam, A., Syafrizayanti, S., Putri, W.H., Ninomiya, M., Koketsu, M., Tanaka, K. and Efdi, M. Isolation of flavonol rhamnosides from Pometia pinnata leaves and investigation of $\alpha$-glucosidase inhibitory activity of flavonol derivatives. Journal of Applied Pharmaceutical Science. 2019; 9(08): 053-065. DOI:10.7324/japs.2019.90808

13. Furay, A., Ahmad, U. and Widodo, S. June. Study on Quality Parameters of Yellow Matoa Fruit (Pometia pinnata) Using Digital Image Processing. In IOP Conference Series: Materials Science and Engineering, 2019; 557(1): 012025. doi:10.1088/1757$899 \times / 557 / 1 / 012025$

14. Galluzzi, L., Senovilla, L., Vitale, I., Michels, J., Martins, I., Kepp, O., Castedo, M. and Kroemer, G. Molecular mechanisms of cisplatin resistance. Oncogene. 2012; 31(15): 1869-1883. DOI: 10.1038/ onc.2011.384

15. De Luca, A., Parker, L.J., Ang, W.H., Rodolfo, C., Gabbarini, V., Hancock, N.C., Palone, F., Mazzetti, A.P., Menin, L., Morton, C.J. and Parker, M.W. A structure-based mechanism of cisplatin resistance mediated by glutathione transferase P1-1. Proceedings of the National Academy of Sciences. 2019; 116(28): 13943-13951. DOI: $10.1073 /$ pnas.1903297116

16. Aldossary, S.A. Review on pharmacology of cisplatin: Clinical use, toxicity and mechanism of resistance of cisplatin. Biomedical and Pharmacology Journal. 2019; 12(1): 7-15. DOI : https://dx.doi. org/10.13005/bpj/1608

17. Wilmes, A., Bielow, C., Ranninger, C., Bellwon, P., Aschauer, L., Limonciel, A., Chassaigne, H., Kristl, T., Aiche, S., Huber, C.G. and Guillou, C. Mechanism of cisplatin proximal tubule toxicity revealed by integrating transcriptomics, proteomics, metabolomics and biokinetics. Toxicology in Vitro. 2015; 30(1): 117-127. DOI: 10.1016/j. tiv.2014.10.006

18. Florea, A.M. and Büsselberg, D. Cisplatin as an anti-tumor drug: cellular mechanisms of activity, drug resistance and induced side effects. Cancers. 2011; 3(1): 1351-1371. DOI: 10.3390/ cancers3011351

19. Eljack, N.D., Ma, H.Y.M., Drucker, J., Shen, C., Hambley, T.W., New, E.J., Friedrich, T. and Clarke, R.J. Mechanisms of cell uptake and toxicity of the anticancer drug cisplatin. Metallomics. 2014; 6(11): 2126-2133. DOI: $10.1039 / c 4 m t 00238 e$

20. Kwon, H.N., Kim, M., Wen, H., Kang, S., Yang, H.J., Choi, M.J., Lee, H.S., Choi, D., Park, I.S., Suh, Y.J. and Hong, S.S. Predicting idiopathic toxicity of cisplatin by a pharmacometabonomic approach. Kidney international. 2011; 79(5): 529-537. DOI: 10.1038/ki.2010.440

21. Amin, A., Abraham, C., Hamza, A.A., Abdalla, Z.A., Al-Shamsi, S.B., Harethi, S.S. and Daoud, S. A standardized extract of Ginkgo biloba neutralizes cisplatin-mediated reproductive toxicity in rats. Journal of Biomedicine and Biotechnology. 2012. DOI: 10.1155/2012/362049

22. Sultana, S., Verma, K. and Khan, R. Nephroprotective efficacy of chrysin against cisplatin-induced toxicity via attenuation of oxidative stress. Journal of Pharmacy and Pharmacology. 2012; 64(6): 872881. DOI: $10.1111 /$ cts. 12480

23. Hu, S., Leblanc, A.F., Gibson, A.A., Hong, K.W., Kim, J.Y., Janke, L.J., Li, L., Vasilyeva, A., Finkelstein, D.B., Sprowl, J.A. and Sweet, D.H. Identification of OAT1/OAT3 as contributors to cisplatin toxicity. Clinical and translational science. 2017; 10(5): 412-420. DOI: $10.1111 /$ cts. 12480

24. Aryal, S., Baniya, M.K., Danekhu, K., Kunwar, P., Gurung, R. and Koirala, N. Total phenolic content, flavonoid content and antioxidant potential of wild vegetables from Western Nepal. Plants. 2019; 8(4): 96. DOI: $10.3390 /$ plants8040096

25. Ni, J., Dong, L., Jiang, Z., Yang, X., Chen, Z., Wu, Y. and Xu, M. Comprehensive transcriptome analysis and flavonoid profiling of Ginkgo leaves reveals flavonoid content alterations in day-night cycles. PloS one. 2018; 13(3): 0193897. DOI: 10.1371/journal. pone.0193897 


\section{GRAPHICAL ABSTRACT}

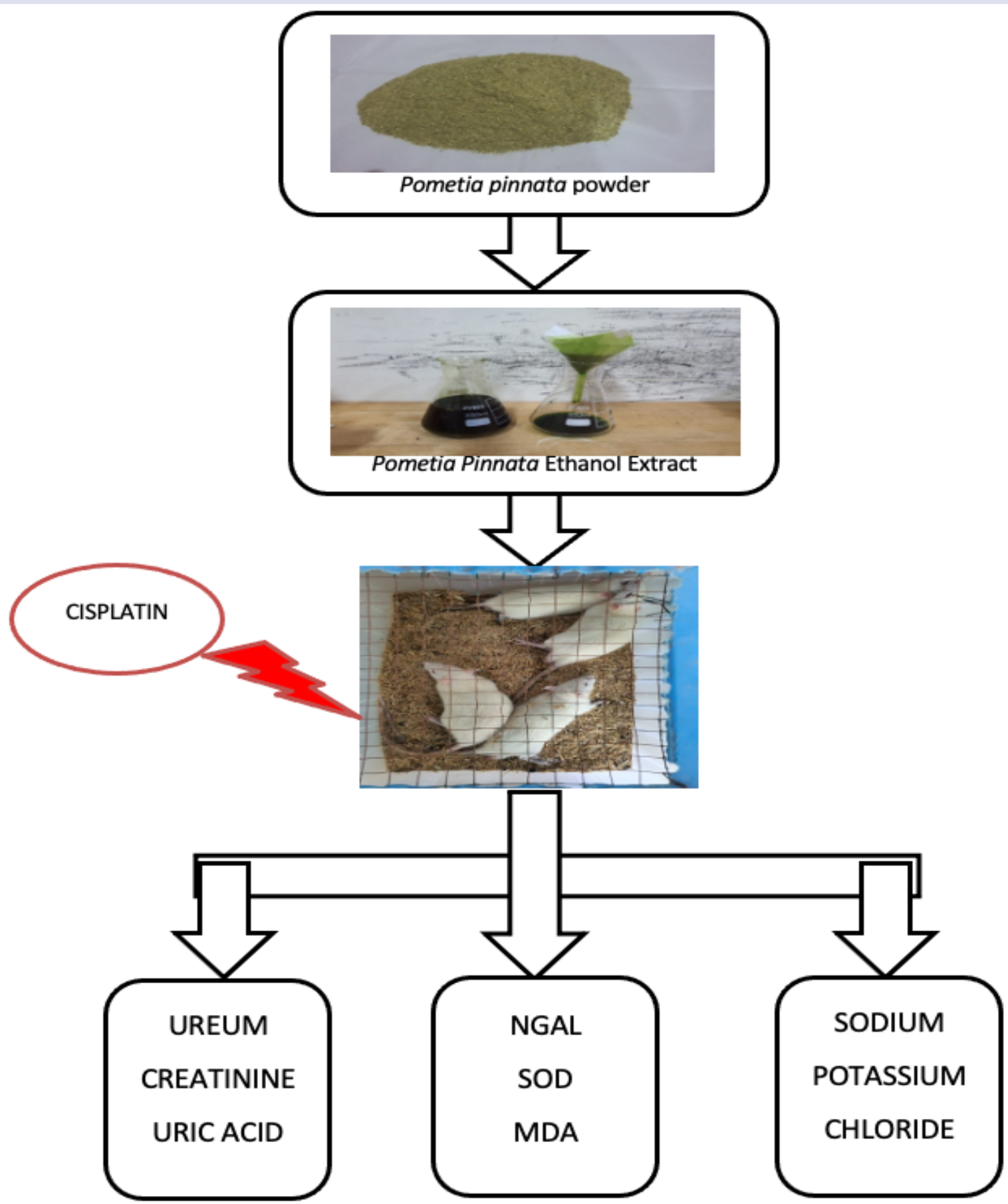




\section{ABOUT AUTHORS}

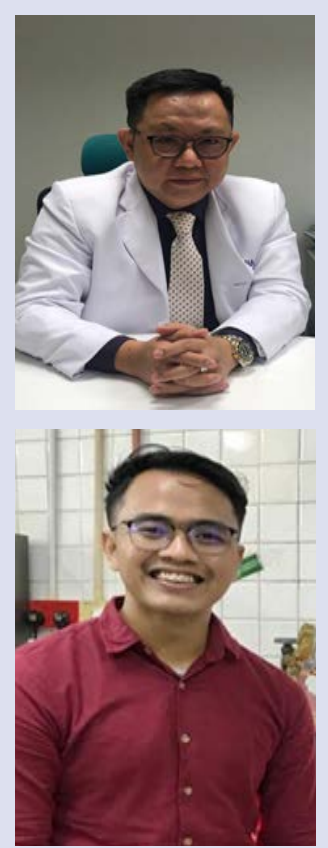

Dr. dr. Adrian Khu, Sp.OT, FICS, AIFO is active lecture in Faculty of Medicine, Universitas Prima Indonesia. His also as an active Medical Orthopedic and active in orthopedic and pharmacology research.

Rony Abdi Syahputra, M.Farm is an active biology lecture in Department of Pharmacology, Faculty Pharmacy, Universitas Sumatera Utara, His also active in pharmacology research especially in toxicology and cardiovascular research. his active as journal reviewer and writing paper in international journal.

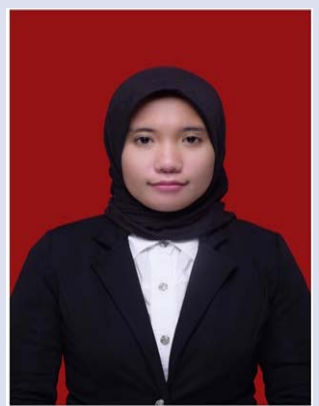

Dr. Putri Cahaya Situmorang, M.Si is an active biology lecture in Department of Biology, Faculty mathematic and natural sciences, Universitas Sumatera Utara, She is also a scientist in Pharmacology, Histology, Physiology and biomedical sciences. She is active as journal reviewer and writing paper in international journal.

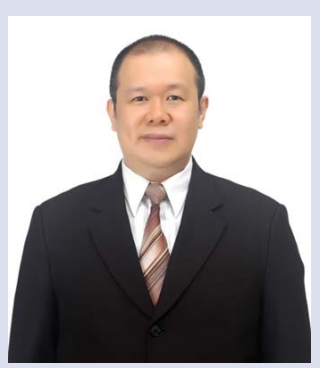

dr. Sukirman Lie, M. Biomed is active lecture in Akademi Keperawatan Colombia Asia Medan. His also as an active medical aesthetic and active pharmacology research.

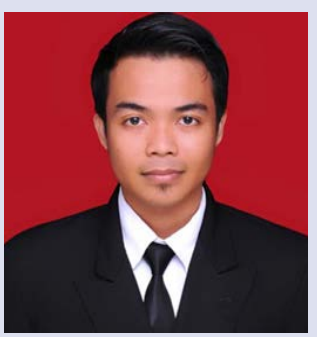

Sony Eka Nugraha, S.Farm., M.Si., Apt is an active biology lecture in Department of Pharmaceutical Biology, Faculty Pharmacy, Universitas Sumatera Utara, His also active in pharmacology and biological research. his active as journal reviewer and writing paper in international journal.

Cite this article: Adrian, Syahputra RA, Lie S, Nugraha SE, Situmorang PC. Amelioration of Cisplatin-Induced Kidney Injury by Pometia pinnata. Pharmacogn J. 2021;13(5): 1257-1268. 